\title{
PELATIHAN IDENTIFIKASI DAN PENGAMATAN BURUNG BAGI PEMANDU WISATA ALAM TANGKOKO DI KOTA BITUNG
}

\author{
Saroyo $^{1)}$ dan Hanny H. Pontororing ${ }^{1)}$ \\ ${ }^{1)}$ Program Studi Biologi FMIPA Universitas Sam Ratulangi \\ Jl. Kampus UNSRAT, Manado 95115 \\ Email: yoyoksumarto@1ycos.com, hpontororing@yahoo.com
}

\begin{abstract}
ABSTRAK
Telah dilakukan kegiatan pengabdian kepada masyarakat tentang pelatihan identifikasi dan pengamatan burung bagi pemandu wisata alam Tangkoko Kota Bitung dengan tujuan untuk meningkatkan pengetahuan dan keterampilan dalam pengamatan dan identifikasi burung. Kegiatan dilaksanakan di Cagar Alam Tangkoko-Batuangus dan Taman Wisata Alam Batuputih Kota Bitung. Kegiatan dilaksanakan selama 10 bulan dari Januari sampai dengan Oktober 2010. Peserta kegiatan berjumlah 52 orang yang terdiri dari pemandu wisata alam dan calon pemandu yang berdomisili di sekitar kawasan konservasi di Kota Bitung. Kegiatan yang telah dilaksanakan meliputi Kegiatan yang telah dilakukan adalah pelatihan tentang birdwatching yang meliputi kegiatan-kegiatan: pemberian teori tentang metode pengenalan dan identifikasi burung dan praktek lapangan dalam penggunaan alat-alat birdwatching dan pengenalan serta identifikasi burung. Evaluasi dilaksanakan dengan metode pre-test dan pos-test untuk mengukur pengetahuan dasar tentang birdwatching dan uji keterampilan dengan parameter: kemampuan mengunakan binoluler, pembuatan sketsa burung, dan ketepatan identifikasi. Hasil kegiatan menunjukkan: pretes rata-rata dari seluruh peserta adalah 4,8 dan hasil post-test rata-rata adalah 7,4 ; dan pengamatan penggunaan binoluler, pembuatan sketsa burung, dan ketepatan identifikasi rata-rata dari seluruh peserta adalah $90 \%$ kategori cukup dan 10\% kategori baik. Dengan hasil di atas maka dapat disimpulkan bahwa kegiatan pengabdian kepada masyarakat telah meningkatkan pengetahuan dan keterampilan dalam pengamatan dan identifikasi burung.
\end{abstract}

Kata kunci: Cagar Alam Tangkoko-Batuangus, pemandu wisata alam, pengamatan burung.

\section{IDENTIFICATION AND OBSERVATION OF BIRDS FOR TANGKOKO ECOTOURISM GUIDES AT BITUNG CITY}

\begin{abstract}
A public service about training in identification and observation of birds for Tangkoko ecotourism guides at Bitung City. The aims of this activity were to improve their knowledge and skill in bird identification and observation. The activity was taken place at Tangkoko-Batuangus Nature Reserve and Batuputih Ecotourism Park, Bitung city during 10 months from January to october 2010.paricipants consisted of 52 members of ecotourism guides and candidates surrounding the conservation areas. asi di Kota Bitung. Kegiatan yang telah dilaksanakan meliputi training activities consisted of teaching in method on introduction and identification of birds, field practicing on bird-watching equipments, observation and identification of birds. Evaluation was done using pre-test and post-test method, and skills in bird-watching skill in using binocular, drawing bird morphology, and identification precisely. Results showed that: average of pre-test was 4.8 while the post-test was 7.4 , the score of using binocular, drawing bird morphology, and identification precisely was $90 \%$ in moderate category and $10 \%$ in good category. From those above results, it can be concluded that this program has improved knowledge and skill in bird identification and observation
\end{abstract}

Keywords: Tangkoko-Batuangus Nature Reserve, Ecotourism guide, bird-watching.

PENDAHULUAN
Taman Wisata Alam Batuputih terletak di Kecamatan Ranowudu (Bitung 
Utara), Kota Bitung, Sulawesi Utara. Luas kawasan ini adalah 615 ha (BKSDA, 2002) dan terdiri atas berbagai tipe vegetasi, yaitu hutan tropis, semak belukar, dan vegetasi pantai. Taman wisata alam adalah kawasan pelestarian alam yang terutama dimanfaatkan untuk pariwisata dan rekreasi alam. Suatu kawasan ditetapkan sebagai Kawasan Taman Wisata Alam, apabila telah memenuhi kriteria sebagai berikut: a) mempunyai daya tarik alam berupa tumbuhan, satwa atau ekosistem gejala alam; serta formasi geologi yang menarik; b) mempunyai luas yang cukup untuk menjamin kelestarian. Potensi dan daya tarik untuk dimanfaatkan bagi pariwisata dan rekreasi alam; dan c) kondisi lingkungan di sekitarnya mendukung upaya pengembangan pariwisata alam (PP No. 68 Tahun 1998).

Kawasan Taman Wisata Alam Batuputih terletak berdekatan dengan Cagar Alam Tangkoko-Batuangus sehingga wisatawan yang berkunjung selalu beranggapan bahwa mereka berwisata di Cagar Alam Tangkoko-Batuangus. Kegiatan wisata alam dilarang dilakukan di cagar alam. Berdasarkan UU No. 5/1990 tentang Konservasi Sumber Daya Alam Hayati dan Ekosistemnya, di dalam cagar alam dapat dilakukan kegiatan untuk kepentingan penelitian dan pengembangan, ilmu pengetahuan, pendidikan, dan kegiatan lainnya yang menunjang budidaya.

Kegiatan wisata alam hanya dapat dilakukan, antara lain di taman wisata alam. Di dalam taman nasional, taman hutan raya, dan taman wisata alam dapat dilakukan kegiatan untuk kepentingan penelitian, ilmu pengetahuan, pendidikan, menunjang budidaya, budaya dan wisata alam. Di dalam Taman Wisata Alam Batuputih hidup berbagai satwa khas yang menjadi objek kunjungan wisatawan, baik lokal maupun mancanegara, antara lain monyet hitam Sulawesi (Macaca nigra), tangkasi (Tarsius spectrum), burung taung (Rhyticeros cassidix), kuskus beruang (Ailurops ursinus), dan sebagainya (Sumarto dan Tallei, 2010).

Keberhasilan industri pariwisata, terutama wisata alam, sangat ditentukan oleh keberadaan pemandu wisata alam. Tugas pemandu adalah memandu perjalanan wisatawan, termasuk di dalamnya memandu perjalanan di objek-objek yang dituju, mengenalkan dan menjelaskan setiap objek wisata, termasuk di dalamnya flora dan fauna khas di Taman Wisata Alam Batuputih.

Oleh karena itu Mitra yang akan dirangkul dalam kegiatan ini adalah: para pemandu wisata alam yang sudah berkecimpung dalam pemanduan, tetapi masih memiliki keterbatasan pengetahuan dan keterampilan dalam pengenalan dan identifikasi burung; para anggota Kelompok Pencinta Alam. Pada umumnya para anggota organisasi ini memilih pekerjaan sebagai pemandu wisata alam sehingga sangat diperlukan pelatihan untuk memberikan bekal pengetahuan dan keterampilan.

Salah satu kelemahan para pemandu adalah kurang menguasai teknik-teknik dalam pengenalan hewan, terutama burung. Hal ini disebabkan karena banyaknya jenis burung serta keterbatasan pendidikan dan pengetahuan pemandu dalam mengidentifikasi burung. Oleh karena itu sangat diperlukan pelatihan tentang pengenalan dan identifikasi burung-burung yangterdapat di Taman Wisata Alam Batuputih, Kota Bitung.

\section{METODE PELAKSANAAN KEGIATAN}

Untuk mengatasi permasalahan kurangnya pengetahuan dan keterampilan dalam identifikasi burung di lapangan, maka yang dilaksanakan di Cagar Alam TangkokoBatuangus dan Taman Wisata Alam Batuputih Kota Bitung. Kegiatan dilaksanakan selama 10 bulan dari Januari sampai dengan Oktober 2010. Peserta kegiatan berjumlah 52 orang yang terdiri dari pemandu wisata alam dan calon pemandu yang berdomisili di sekitar kawasan konservasi di Kota Bitung. Kegiatan yang telah dilakukan adalah pelatihan tentang birdwatching yang meliputi kegiatankegiatan:

a. Pemberian teori tentang metode pengenalan dan identifikasi burung.

Teori meliputi: morfologi, klasifikasi, ekologi, perilaku, dan birdwatching. Berbagai pustaka yang digunakan meliputi: Panduan Lapangan BurungBurung di Kawasan Wallacea. Sulawesi, Maluku dan Nusa Tenggara (Coates \& Bishop); Ensiklopedi Indonesia: Seri Fauna Burung (Van Hoeve, 1996); A 
Photographic Guide to the Birds of Indonesia (Strange, 2001); TeknikTeknik Ekspedisi Lapangan Suervei Burung (Bibby et al., 2000); Advanced Practical Zoology (Verma \& Srivastava, 1996); dan A Manual of Practical Zoology Chordates (Verma \& Chand, 1997).

b. Praktek lapangan dalam penggunaan alat-alatbirdwatching dan pengenalan serta identifikasi burung:

- Pengenalan dan cara pengoperasian beberapa peralatan yang penting dalam pengamatan burung, antara lain buku catatan, pensil, karet penghapus, teropong, buku pengenalan jenis, kamera, dan alar perekan suara.

- Pengenalan aturan cara berpakaian selama kegiatan pengamatan burung yang meliputi: penggunakan pakaian berwarna gelap, nyaman dikenakan, memiliki kantung untuk tempat buku catatan, menyerap keringat dan mudah kering jika basah; membiasakan menggunakan pakaian lengan panjang; menggunakan topi, tidak bersuara (ribut) dan berjalan perlahan, jika mungkin mencari tempat untuk bersembunyi; mengamati burung dalam posisi yang nyaman; membuat catatan lapangan yang mencakup sketsa burung, waktu, lokasi, dan aktivitas burung.

- Identifikasi burung dengan menggunakan panduan: Panduan Lapangan Burung-Burung di Kawasan Wallacea. Sulawesi, Maluku dan Nusa Tenggara (Coates \& Bishop); A Photographic Guide to the Birds of Indonesia (Strange, 2001).

c. Tahap evaluasi dengan metode:

- Pre-test dan pos-test untuk mengukur pengetahuan dasar tentang birdwatching.

- Uji keterampilan dengan parameter: kemampuan mengunakan binoluler, pembuatan sketsa burung, dan ketepatan identifikasi.

\section{HASIL DAN PEMBAHASAN}

Perubahan sebelum dan setelah dilaksanakannya program pelatihan adalah sebagai berikut:

1. Hasil pre-tes rata-rata dari seluruh peserta adalah 4,8 dan hasil post-test rata-rata adalah 7,4 .

2. Pengamatan penggunaan binoluler, pembuatan sketsa burung, dan ketepatan identifikasi rata-rata dari seluruh peserta adalah 90\% kategori cukup dan 10\% kategori baik.

Dengan hasil di atas, maka dapat dikatakan bahwa program ini telah berhasil dalam meningkatkan pengetahuan dan keterampilan dalam identifikasi dan pengamatan burung di Taman Wisata Alam Batuputih.

Menurut teori pendidikan, dalam proses pembelajaran terdapat 3 domain yang harus dicapai dalam perubahan perilaku belajar, yaitu kognitif (pengetahuan, aspek intelektual), afektif (aspek etika dan moral), serta psikomotor (keterampilan). Dalam pelatihan ini, ketiga domain tersebut dapat tercapai.

$\begin{array}{lrr} & \text { Aspek kognitif dengan pemberian } \\ \text { materi tentang dasar-dasar } & \text { ilmiah } \\ \text { birdwatching dan beberapa } & \text { aspek }\end{array}$ biologi/ekologi burung. Aspek afektif dicapai dengan pemberian materi tentang cara berpakaian, berjalan, dan bekerja sama dalam tim pengamatan burung. Aspek psikomotor dengan melatih menggunakan binokuler, membuat sketsa, dan menggunakan buku panduan dalam identifikasi burung.

Kelompok pemandu wisata alam Tangkoko merupakan unsur penting dalam kegiatan kepariwisataan alam di Taman Wisata Alam Batuputih, Kota Bitung di samping faktor asesibilitas, akomodasi dan daya tarik/atraksi wisata. Sebagai gambaran, hasil-hasil survei oleh Saroyo dari tahun 2006-2007 (Potensi Ekoturisme di Taman Wisata Alam Batuputih, Kota Bitung, Sulawesi Utara, Pacific Journal, V. 2 No. 5 Juli 2010) adalah sebagai berikut ini.

Rekapitulasi jumlah kunjungan selama satu tahun: kunjungan wisatawan asing sebanyak 2.419 kunjungan $(32,5 \%)$ dan domestik sebanyak 5.030 kunjungan $(67,5 \%)$. Wisatawan domestik pada umumnya tidak melakukan ekoturisme, melainkan lebih 
banyak mengunjungi pantai untuk berenang, duduk-duduk, atau ibadah.

Ditinjau dari luas area TWA dan banyaknya obyek yang menjadi daya tarik wisatawan, serta waktu kunjungan yang dapat dilakukan selama 24 jam, maka jumlah kunjungan ini dapat ditingkatkan sampai mencapai kuota 100 kunjungan perhari. Jika jumlah ini tercapai, maka jumlah masyarakat lokal yang dapat direkrut sebagai pemandu akan semakin banyak sehingga kesejahteraan masyarakat di sekitar kawasan konservasi akan meningkat pula.

Rekapitulasi waktu kunjungan wisatawan asing, waktu kunjungan paling banyak dilakukan pada siang-sore $(71,1 \%)$, diikuti pagi-siang $(18,9 \%)$, sepanjang hari $(10,0 \%)$ dan tidak ada kunjungan pada malam hari $(0,0 \%)$. Kunjungan pagi-siang dilakukan wisatawan dengan mengunjungi tarsius yang kembali ke tempat tidur dari pengembaraan malam yang dilanjutkan dengan treking sambil menuju ke kelompok yaki. Sebaliknya, kunjungan siang-sore dilakukan dengan treking sambil mencari kelompok yaki dan diakhiri dengan kunjungan ke tarsius untuk mengamati tarsius waktu keluar dari tempat tidurnya.

Kunjungan malam hari sebenarnya dapat ditawarkan kepada wisatawan, terutama yang akan mengamati kehidupan fauna nokturnal, seperti burung malam, serangga, serta kelelawar. Sampai saat ini potensi tersebut belum dikembangkan dengan baik sebagai salah satu obyek kunjungan wisatawan.

Obyek kunjungan wisatawan di TWA Batuputih meliputi: primata (yaki dan tarsius) merupakan obyek yang paling banyak dikunjungi $(53,8 \%)$, diikuti burung $(6,4 \%)$, snorkeling/berenang $\quad(4,5 \%)$, serangga $(0,3 \%)$, dan lain-lain $(34,9 \%)$. Dari data tersebut, primata yang terdiri dari yaki dan tarsius merupakan obyek yang paling menarik, bahkan sudah menjadi spesies bendera (Flagship species). Walaupun demikian, banyak obyek lain $(34,9 \%)$ yang belum ditonjolkan yang sebenarnya juga dapat dijadikan daya tarik wisata, misalnya pohon/tanaman, kemah di tepi pantai, dan sebagainya.

Hal yang paling penting dalam dengan kemampuan di dalam birdwatching bagi pemandu wisata alam adalah peningkatan tarif pemanduan. Pemandu umum biasanya dihargai sekitar Rp200.000/hari sedangkan pemandu pada birdwatching dihargai minimal $\mathrm{Rp}$. 400.000/hari. Dengan demikian kegiatan pelatihan ini memiliki peran strategis di dalam peningkatan penghasilan bagi pemandu. Bagi peserta yang memiliki pekerjaan lainnya, wawasan konservasi burung merupakan modal penting dalam konservasi sumber daya alam dan ekosistemnya yang diwujudkan dalam perilaku kesehariannya.

\section{KESIMPULAN}

Kegiatan pelatihan dalam identifikasi dan pengamatan burung bagi pemandu wisata alam Tangkoko di Kota Bitung telah meningkatkan pengetahuan dan keterampilan dalam identifikasi dan pengamatan burung di Taman Wisata Alam Batuputih.

\section{DAFTAR PUSTAKA}

BKSDA [Balai Konservasi Sumber Daya Alam]. 2002. Kawasan Konservasi di Sulawesi Utara. Departemen Kehutanan. Manado.

Bibby, C., M. Jones, dan S. Marsden. 2000. Teknik-Teknik Ekspedisi Lapangan Suervei Burung. Birdlife. Bogor.

Coates, B.J. and K.D. Bishop. 2000. Panduan Lapangan Burung-Burung di Kawasan Wallacea. Sulawesi, Maluku dan Nusa Tenggara. Birdlife International-Indonesia Program \& Dove Publications. Bogor.

PP No. 68 Tahun 1998 tentang Kawasan Suaka Alam dan Kawasan Pelestarian Alam.

UU No. 5/1990 tentang Konservasi Sumber Daya Alam Hayati dan Ekosistemnya.

Saroyo. 2010. Potensi Ekoturisme di Taman Wisata Alam Batuputih, Kota Bitung, Sulawesi Utara. Pacific Journal, V. 2 No. 5.

Strange, M. 2001. A Photographic Guide to the Birds of Indonesia. Periplus Editions (HK) Ltd. Singapore. 
Sumarto, S. and T. Tallei. 2010. Climbing Tangkoko Mountain: Conservation Education Medium. Penerbit Halaman Moeka Publishing. Jakarta.

Van Hoeve, W. 1996. Ensiklopedi Indonesia. Seri Fauna. Burung. Penerbit PT Ichtiar Baru Van Hoeve. Jakarta.

Verma, P.S and P.C. Srivastava. 1996. Advanced Practical Zoology. S. Chand \& Company LTD. New Delhi.

Verma, P.S. and S. Chand. 1997. A Manual of Practical Zoology Chordates. S. Chand \& Company LTD. New Delhi. 